\title{
Alanine Enhances Jejunal Sodium Absorption in the Presence of Glucose: Studies in Piglet Viral Diarrhea
}

\author{
J. MARC RHOADS, R. JOHN MACLEOD, AND J. RICHARD HAMILTON \\ Research Institute, The Hospital for Sick Children, and Division of Gastroenterology, Department of Paediatrics, \\ University of Toronto, Toronto, Ontario, Canada
}

\begin{abstract}
We measured the response of jejunal sodium (Na) absorption to neutral amino acid (L-alanine) and to dipeptides (L-alanyl-L-alanine, glycylsarcosine) in normal piglets and in piglets with acute viral diarrhea after experimental infection with transmissible gastroenteritis (TGE) virus. In the TGE jejunum villi were blunted, crypts were deepened, and the epithelium was composed of relatively undifferentiated cells with reduced disaccharidase, decreased sodium-potassium-stimulated ATPase, and elevated thymidine kinase activities. The response of $\mathrm{Na}$ absorption to a maximal concentration of $L$-alanine (20 $\mathrm{mM})$ or D-glucose $(30 \mathrm{mM})$ was significantly blunted in TGE jejunum in Ussing chambers. However, the addition of L-alanine together with D-glucose caused a significantly greater increment of $\mathrm{Na}$ absorption than either L-alanine or D-glucose alone in control and TGE tissue. The effect of $\mathrm{Na}$ absorption of the dipeptide $\mathrm{L}$-alanyl-L-alanine (10 $\mathrm{mM}$ ), which was rapidly hydrolyzed by control and TGE mucosa, was similar to that of $\mathrm{L}$-alanine $(20 \mathrm{mM})$, while glycylsarcosine, a poorly hydrolyzed dipeptide, did not change net $\mathrm{Na}$ absorption in the jejunum. Our data support the concept of separate carrier systems for neutral amino acid and hexose in the crypt-type intestinal epithelium characterizing viral enteritis. We speculate that a sodiumcotransporting amino acid, if added to oral glucose-electrolyte solutions, could benefit oral rehydration therapy in acute viral diarrhea; neither of the dipeptides tested here can be expected to enhance absorption to any greater extent than its constituent amino acids. (Pediatr Res 20: 879883,1986 )
\end{abstract}

\section{Abbreviations}

Isc, short-circuit current

$\mathrm{Na}$, sodium

$\mathbf{J}_{\mathrm{ms}}^{\mathrm{Na}}$, Na flux from mucosa to serosa

$J_{\mathrm{sm}}^{\mathrm{Na}}$, Na flux from serosa to mucosa

$J_{\text {net, }}^{N a}$, net Na flux

$\Delta \mathbf{J}_{\text {net }}^{\mathrm{Na}}$, increment in net $\mathrm{Na}$ flux

$\mathrm{Na}^{+}-\mathrm{K}^{+}$-ATPase, sodium-potassium-stimulated adenosinetriphosphatase

ORT, oral rehydration therapy

TGE, transmissible gastroenteritis

WHO, World Health Organization

Received January 23, 1986; accepted April 30, 1986.

Supported by a grant from the Medical Research Council of Canada. J.M.R. was a recipient of a research fellowship from the Canadian Cystic Fibrosis Foundation.

All correspondence and requests for reprints should be addressed to J. Richard Hamilton, M.D., Division of Gastroenterology, The Hospital for Sick Children, 555 University Avenue, Toronto, Ontario, Canada M5G 1 X8.
3-O-MG, 3-O-methyl-D-glucose

Ala-Ala, L-alanyl-L-alanine

ORT has greatly improved the outlook for millions of babies afflicted each year with acute enteritis. The current WHO/ UNICEF formulation for oral rehydration has been very effective in restoring the water and electrolyte status of patients with diarrhea, but it does not diminish stool losses $(1,2)$. To accelerate clinical recovery and promote general acceptance of ORT, a solution that actually reduces diarrheal volume would be very desirable.

One theoretical approach to improving standard ORT is to incorporate additional nonionic solute in its formulation to promote water and salt absorption in the diseased intestine. To evaluate the pathophysiological basis for such an approach we studied the effect of a neutral amino acid and certain dipeptides on $\mathrm{Na}$ flux in the small intestine during acute viral enteritis. Hellier et al. (3) demonstrated that certain amino acids promote small intestinal absorption in man (3). Furthermore, preliminary studies have shown a beneficial effect of an amino acid-containing oral rehydration solution in treating diarrhea $(4,5)$. Our current in vitro data provide a theoretical basis for the clinical testing of oral rehydration solutions supplemented with neutral amino acid.

\section{MATERIALS AND METHODS}

Animal techniques. Two-wk-old York Landrace piglets were weaned and maintained for 3 days on evaporated cows' milk; 21 received a standard intragastric inoculum of the Purdue strain of TGE virus (6) and 28 uninfected littermates served as agematched controls. Infected pigs were killed $40 \mathrm{~h}$ later by parenteral injection of $325 \mathrm{mg}$ of pentobarbital $\mathrm{Na}$. Although vomiting and diarrhea had developed in TGE-infected piglets, their weights $(2550 \pm 90 \mathrm{~g})$ did not differ significantly from those of controls $(2750 \pm 90 \mathrm{~g})$

Enzyme and transport studies. Immediately after death, beginning $10 \mathrm{~cm}$ distal to the ligament of Treitz, the first $8 \mathrm{~cm}$ of jejunum was removed quickly, flushed with normal saline, and mounted in Ussing chambers. The next $25 \mathrm{~cm}$ was removed and flushed, the proximal $2 \mathrm{~cm}$ taken for light microscopy, and the mucosa scraped off the remainder with a glass slide, homogenized, and frozen at $-40^{\circ} \mathrm{C}$. These mucosal homogenates were assayed for total sucrase and lactase (7), $\mathrm{Na}^{+}-\mathrm{K}^{+}$-ATPase (8), and thymidine kinase (9) activities. For ion flux measurements, jejunal mucosa was stripped of muscle, opened, and mounted quickly in modified Ussing chambers (exposing an area of 1.29 $\mathrm{cm}^{2}$ ) (9). Each side of the tissue was bathed at $37^{\circ} \mathrm{C}$ in $10 \mathrm{ml}$ 
oxygenated Krebs-Ringer bicarbonate buffer $(\mathrm{pH} 7.4)$ containing (mM): Na 143, potassium 10, magnesium 1.1, calcium 1.25, chloride $128, \mathrm{HCO}_{3} 25, \mathrm{H}_{2} \mathrm{PO}_{4} 2$, and acetate 3 as a source of energy. Jejunal tissue was mounted in the chambers within 30 min of the piglet's death and continuously short-circuited, with the short-circuit current adjusted at 10 -min intervals (10). Transmucosal potential difference and conductance were stable for the 2-h study periods, indicating viability of the preparations.

${ }^{22} \mathrm{Na}$ (Amersham, Montreal, Canada) was added to the mucosal or serosal chamber, and after a 15-min equilibration period, unidirectional $\mathrm{Na}$ fluxes based on the rate of appearance of label in the opposite chamber were calculated from 1-ml samples drawn at 10 -min intervals $(10,11)$. After $55 \mathrm{~min}, 5 \mathrm{ml}$ of Krebs buffer containing L-alanine $(5,10,20$, or $50 \mathrm{mM}$, Sigma Chemical Co., St. Louis, MO), Ala-Ala (10 mM, Sigma Chemical Co.), D-glucose $(5,30,50$ or $100 \mathrm{mM}$, BDH Chemicals, Toronto, Ontario, Canada), glycylsarcosine $(5,20$, or $50 \mathrm{mM}$, Sigma Chemical Co.), L-alanine (50 $\mathrm{mM})$ and D-glucose $(30 \mathrm{mM})$, or L-alanine (50 mM) and 3-O-methyl-D-glucose (3-O-MG, $30 \mathrm{mM}$, Sigma Chemical Co.) was added to the mucosal and serosal chambers to maintain osmotic balance, as previously described (12). Fifteen min later, unidirectional $\mathrm{Na}$ fluxes again were measured at $10-\mathrm{min}$ intervals for $1 \mathrm{~h}$. $\mathrm{J}_{\mathrm{ms}}^{\mathrm{Na}}$ and $\mathrm{J}_{\mathrm{sm}}^{\mathrm{Na}}$ were determined from paired jejunal segments, and net $\mathrm{Na}$ flux was calculated using the formula $\mathrm{J}_{\mathrm{net}}^{\mathrm{Na}}=\mathrm{J}_{\mathrm{ms}}^{\mathrm{Na}}-\mathrm{J}_{\mathrm{sm}}^{\mathrm{Na}}$. When conductance in paired tissues differed by more than $20 \%$, data from the chambers were discarded.

In chambers containing control or TGE tissue, we estimated L-alanyl-L-alanine hydrolysis in the mucosal buffer using ion exchange chromatography to measure the remaining dipeptide. After a 10 -min incubation the L-alanyl-L-alanine peak, separate

Table 1. Mucosal structure and enzymes in piglet jejunum (mean $\pm S E M)$

\begin{tabular}{lcc}
\hline & Controls & TGE* \\
\hline Structure & & \\
$\quad$ Villus ht $(\mu \mathrm{m})$ & $294.6 \pm 12.8(22) \dagger$ & $123.8 \pm 17.1(16)$ \\
Crypt depth $(\mu \mathrm{m})$ & $134.4 \pm 6.2(22)$ & $189.1 \pm 9.8(16)$ \\
$\quad$ Villus/crypt ratio & $2.3 \pm 0.1(22)$ & $0.7 \pm 0.1(16)$ \\
Enzyme activities & & \\
$\quad$ Sucrase $\left(\mathrm{U} \cdot \mathrm{g}^{-1}\right)$ & $55.3 \pm 7.0(28)$ & $2.5 \pm 0.5(21)$ \\
Lactase $\left(\mathrm{U} \cdot \mathrm{g}^{-1}\right)$ & $72.9 \pm 6.6(28)$ & $4.5 \pm 0.7(21)$ \\
Na $-\mathrm{K}^{+}-\mathrm{ATPase}$ & $90.6 \pm 6.8(28)$ & $42.4 \pm 8.5(21)$ \\
$\quad\left(\mathrm{U} \cdot \mathrm{g}^{-1}\right)$ & & \\
Thymidine kinase & $9.7 \pm 0.9(28)$ & $42.2 \pm 0.9(21)$ \\
$\quad\left(\mathrm{pmol} \cdot \mathrm{mg}^{-1} \cdot \mathrm{h}^{-1}\right)$ & & \\
\hline
\end{tabular}

* All TGE data differ significantly from control data $(p<0.001)$. $\uparrow$ Number of animals is given in parentheses. from that for $L$-alanine, was compared with standards of known concentration.

Microscopic studies. Tissue was fixed in Bouin's solution, blocked in paraffin, and stained with hematoxylin and eosin. Using a calibrated micrometer eyepiece to measure 10 to 15 representative crypt-villus units, one observer examined all sections with light microscopy without prior identification.

Statistics. Data were compared statistically using Student's $t$ test.

\section{RESULTS}

Mucosal structure and enzymes (Table 1). Compared with noninfected controls, in piglets with TGE, jejunal villi were blunted $(p<0.001)$ and crypts deepened $(p<0.001)$ with substantial acute inflammation in the lamina propria $40 \mathrm{~h}$ after TGE infection (Table 1). Mucosal sucrase, lactase, and $\mathrm{Na}^{+}-\mathrm{K}^{+}-$ ATPase activities were diminished $(p<0.001)$, whereas the proliferative marker thymidine kinase was elevated $(p<0.001)$ in TGE tissue. These findings, consistent with our earlier observations of this disease (13), suggest that the jejunal epithelium at the 40-h acute diarrheal phase of TGE was composed of relatively undifferentiated crypt-type enterocytes.

Effect of different concentrations of L-alanine and D-glucose on electrical properties and $\mathrm{Na}$ flux. The response of Isc in control piglet jejunum to increasing concentrations of $\mathrm{L}$-alanine and $\mathrm{D}$ glucose is shown in Figure 1. Maximal responses $(\Delta \mathrm{Isc})$ were noted at $20 \mathrm{mM} \mathrm{L}$-alanine and $30 \mathrm{mM}$ D-glucose; maximal increases of net $\mathrm{Na}$ flux were also noted at these concentrations. In TGE jejunum, maximal response occurred at the same concentrations.

Table 2 summarizes electrical and $\mathrm{Na}$ flux responses to $\mathrm{L}-$ alanine and D-glucose in short-circuited control and TGE jejunum. Under basal conditions in the absence of $\mathrm{L}$-alanine or Dglucose, unidirectional $\mathrm{Na}$ fluxes were reduced in TGE jejunum compared with controls; net $\mathrm{Na}$ flux in TGE jejunum was secretory and did not differ from that in controls. After addition of either L-alanine or D-glucose to the mucosal and serosal buffers, control jejunum responded as expected with significant increases in $J_{\mathrm{ms}}^{\mathrm{Na}}$ and $\mathrm{J}_{\mathrm{net}}^{\mathrm{Na}}$ TGE jejunum also responded to $\mathrm{L}-$ alanine with increases in $\mathrm{J}_{\mathrm{ms}}^{\mathrm{Na}}$ and $\mathrm{J}_{\text {net }}^{\mathrm{Na}}$, and to D-glucose with increases in $\mathrm{J}_{\text {net }}^{\mathrm{Na}}$; however, these increments were less than those observed in controls $(p<0.01)$. Addition of L-alanine or Dglucose did not alter $\mathbf{J}_{\mathrm{sm}}^{\mathrm{Na}}$ in either control or TGE epithelia.

Data from experiments comparing the $\mathrm{Na}$ flux responses to $\mathrm{L}-$ alanine plus D-glucose with those to maximal concentrations of L-alanine or D-glucose alone in short-circuited jejunum are shown in Figure 2. In paired sets of chambers, response to the two substrates together exceeded the response to either L-alanine $(p<0.01)$ or D-glucose $(p<0.05)$ in control and in TGE

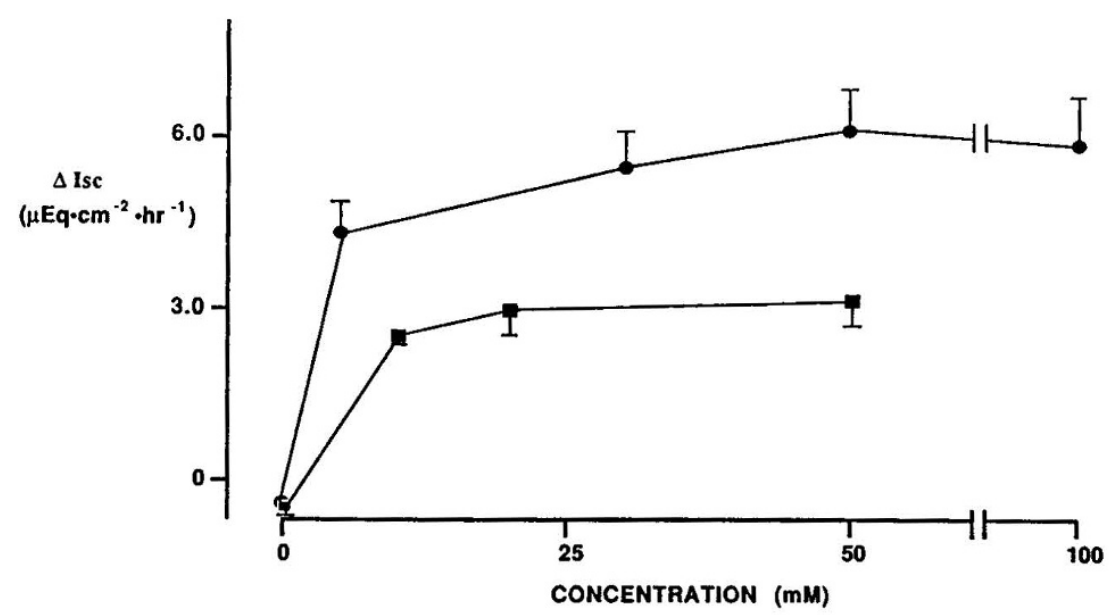

Fig. 1. Increase of $\Delta \mathrm{Isc}$ in response to different concentrations of L-alanine $(\boldsymbol{\square})$ and D-glucose $(\bullet)$ in control piglet jejunum (mean \pm SEM). 
Table 2. Transmucosal unidirectional $\left(J_{m s}^{N a}, J_{s m}^{N a}\right)$ and net Na fluxes $\left(J_{n e}^{N a}\right)$, conductance, and Isc: response to L-alanine and D-glucose in TGE jejunum (mean $\pm S E M$ )

\begin{tabular}{|c|c|c|c|c|c|c|c|}
\hline & \multicolumn{5}{|c|}{$\mathrm{Na}$ flux $\left(\mu \mathrm{Eq} \cdot \mathrm{cm}^{-2} \cdot \mathrm{h}^{-1}\right)$} & \multirow{2}{*}{$\begin{array}{c}\text { Conductance } \\
(\mathrm{mmho} \\
\left.\mathrm{cm}^{-2}\right)\end{array}$} & \multirow{2}{*}{$\begin{array}{c}\mathrm{Isc} \\
\left(\mu \mathrm{Eq} \cdot \mathrm{cm}^{-2} \cdot \mathrm{h}^{-1}\right)\end{array}$} \\
\hline & $n$ & $J_{\mathrm{ms}}$ & $\mathrm{J}_{\mathrm{sm}}$ & $\mathrm{J}_{\text {net }}$ & $\Delta \mathrm{J}_{\text {net }}$ & & \\
\hline \multicolumn{8}{|l|}{ Basal } \\
\hline Controls & 15 & $9.3 \pm 0.7$ & $10.6 \pm 0.8$ & $-1.4 \pm 0.6$ & & $20.5 \pm 1.2$ & $2.7 \pm 1.2$ \\
\hline TGE & 15 & $5.9 \pm 0.2 *$ & $7.6 \pm 0.3^{*}$ & $-1.7 \pm 0.3$ & & $14.0 \pm 0.5^{*}$ & $1.8 \pm 0.1^{*}$ \\
\hline \multicolumn{8}{|c|}{ L-Alanine $(20 \mathrm{mM})$} \\
\hline Controls & 15 & $11.9 \pm 1.0 \dagger$ & $10.8 \pm 0.6$ & $1.1 \pm 0.7 \ddagger$ & $2.5 \pm 0.4$ & $27.3 \pm 1.4 \div$ & $5.8 \pm 0.5 \ddagger$ \\
\hline TGE & 15 & $7.9 \pm 0.5^{*, \dagger}$ & $8.5 \pm 0.4^{*}$ & $-0.6 \pm 0.4 \dagger$ & $1.1 \pm 0.3^{*}$ & $17.4 \pm 0.8^{*} \ddagger$ & $3.6 \pm 0.4^{*} \ddagger$ \\
\hline \multicolumn{8}{|l|}{ Basal } \\
\hline Controls & 8 & $9.5 \pm 0.7$ & $10.6 \pm 0.4$ & $-1.1 \pm 0.4$ & & $20.3 \pm 1.2$ & $2.5 \pm 0.1$ \\
\hline TGE & 9 & $6.8 \pm 0.7^{*}$ & $8.0 \pm 0.7^{*}$ & $-1.2 \pm 0.4$ & & $16.6 \pm 1.7$ & $1.8 \pm 0.1^{*}$ \\
\hline \multicolumn{8}{|c|}{ D-Glucose $(30 \mathrm{mM})$} \\
\hline Controls & 8 & $14.8 \pm 0.7 \ddagger$ & $9.8 \pm 0.5$ & $5.0 \pm 0.5 \ddagger$ & $6.1 \pm 0.7$ & $28.3 \pm 3.1 \ddagger$ & $6.8 \pm 0.8 \ddagger$ \\
\hline TGE & 9 & $8.1 \pm 1.1^{*}$ & $7.9 \pm 0.7 \S$ & $0.3 \pm 0.4^{*,+}$ & $1.5 \pm 0.4^{*}$ & $20.2 \pm 2.0^{*}$ & $3.8 \pm 0.5^{*} \div$ \\
\hline
\end{tabular}

$* p<0.01$ compared with controls.

$\dagger p<0.05$ compared with basal.

$\ddagger p<0.01$ compared with basal.

$\S p<0.05$ compared with controls.

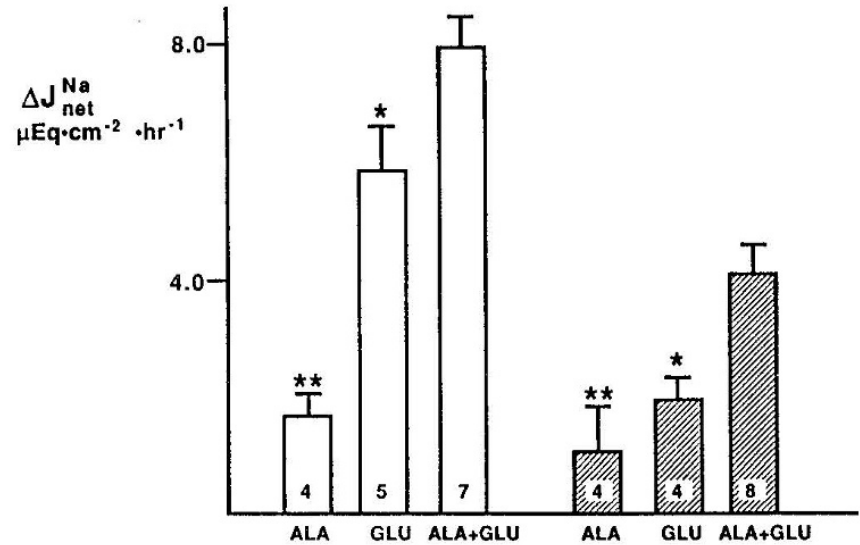

Fig. 2. Response of Na absorption in control ( $\square$ ) and TGE (ש्Z) piglet jejunum after addition of L-alanine $(A L A)(50 \mathrm{mM})$, D-glucose $(G L U)$ $(30 \mathrm{mM})$, and L-alanine $(50 \mathrm{mM})$ with D-glucose $(30 \mathrm{mM})$ (ALA + GLU). Paired observations in same epithelia. Significant differences between responses to L-alanine with $\mathrm{D}$-glucose and to $\mathrm{L}$-alanine or $\mathrm{D}$ glucose are shown by one $(p<0.05)$ or two $(p<0.01)$ asterisks. Na absorptive response is significantly reduced in TGE tissue compared with controls $(p<0.01)$ when D-glucose or L-alanine with D-glucose is added. Numerals and bars indicate number of studies (mean \pm SEM).

jejunum. We compared the effect of L-alanine plus D-glucose with that of L-alanine plus the nonmetabolizable hexose 3-OMG in control and TGE jejunum; in both study groups the $\Delta \mathbf{J}_{\text {net }}^{\mathrm{Na}}$ in response to $\mathrm{L}$-alanine with $\mathrm{D}$-glucose was the same as that to L-alanine with 3-O-MG (Fig. 3).

In control jejunum, unidirectional $\mathrm{Na}$ fluxes in the presence of D-glucose at 30,50 , and $100 \mathrm{mM}$ were equivalent. This indicates that above the maximal concentration, an increase in osmolarity in the range tested did not significantly alter jejunal $\mathrm{Na}$ transport or passive flux.

Electrical responses of the tissues to L-alanine and D-glucose were in keeping with the $\mathrm{Na}$ transport data described above. In both groups of piglets increments in Isc were equivalent to increments in $\mathbf{J}_{\text {net }}^{\mathrm{Na}}$ (Fig. 1, Table 2). Isc increased significantly more after L-alanine plus D-glucose than after either alone $(p<$ 0.05 ) in control and TGE tissue. Epithelial conductance (G), increased to the same extent $(p<0.01)$ after L-alanine or Dglucose in both control and TGE jejunum (Table 2). In the experiments summarized in Figure 2, L-alanine plus D-glucose increased conductance by $8.4 \pm 2.2 \mathrm{mmho} \cdot \mathrm{cm}^{-2}$, an increment

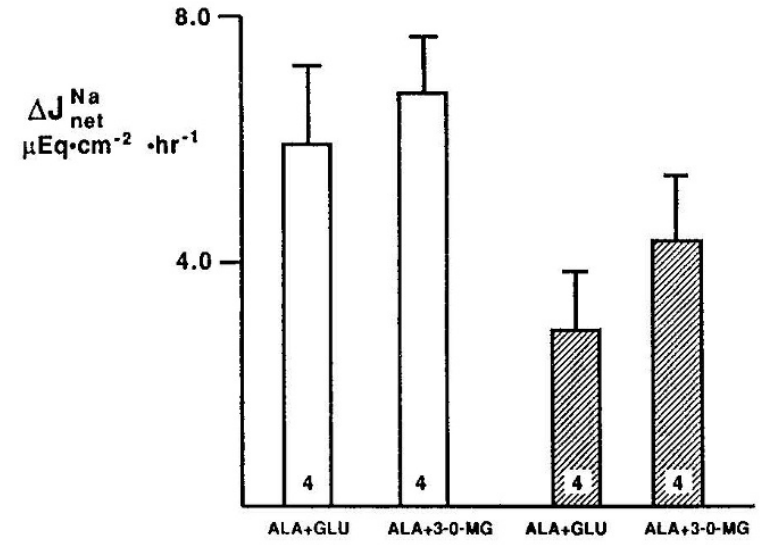

Fig. 3. Response of flux $\left(\Delta \mathrm{J}_{\mathrm{net}}^{\mathrm{Na}}\right)$ in control $(\square)$ and TGE (שיC) piglet jejunum after addition of $\mathrm{L}$-alanine and $\mathrm{D}$-glucose or $\mathrm{L}$-alanine and 3-OMG. Response to L-alanine + 3-O-MG in TGE jejunum is significantly less than that of control jejunum $(p<0.05)$ (mean \pm SEM).

that did not differ from the increase after L-alanine $(3.8 \pm 1.0$ $\left.\mathrm{mmho} \cdot \mathrm{cm}^{-2}\right)$ or D-glucose $\left(4.4 \pm 1.7 \mathrm{mmho} \cdot \mathrm{cm}^{-2}\right)$ alone.

Effect of glycylsarcosine and Ala-Ala on Na transport. Added to control jejunum, the synthetic dipeptide glycylsarcosine, known not to be susceptible to hydrolysis at the brush border membrane (14), increased Isc in a concentration-dependent manner at 5, 20, and $50 \mathrm{mM}$ but did not affect $\mathrm{J}_{\mathrm{ms}}^{\mathrm{Na}}$ or $\mathrm{J}_{\mathrm{net}}^{\mathrm{Na}}$ (Fig. 4).

Control epithelium responded to Ala-Ala with an increase in net $\mathrm{Na}$ absorption ( $p<0.05$ compared with basal period) similar to that occurring in response to L-alanine. However, in these preparations of TGE jejunum, $J_{\text {net }}^{\mathrm{Na}}$ did not increase significantly above basal $\mathrm{Na}$ flux after addition of either the amino acid or the dipeptide (Fig. 5), although $\mathrm{J}_{\mathrm{ms}}^{\mathrm{Na}}$ increased $(p<0.05)$. Ion exchange chromatography of the mucosal buffer solution containing Ala-Ala after 10-min exposure to control mucosa showed complete hydrolysis of Ala-Ala ( $n=4$ chambers); in chambers containing TGE mucosa $(n=3)$, hydrolysis was $86 \%$ complete.

\section{DISCUSSION}

Our studies have demonstrated an effect of L-alanine and Dglucose on sodium transport in control and TGE jejunum that significantly exceeded the response to maximal concentrations of either substrate alone. This additive effect might have been due to the presence of two noncompeting transport sites or to 


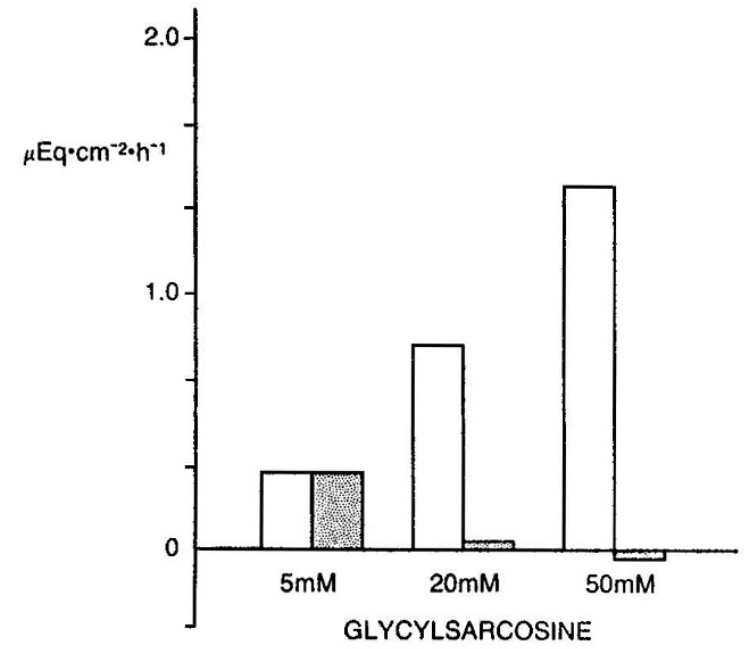

Fig. 4. Increases of Isc ( $\square$ ) and $J_{\text {net }}^{N a}$ (㽞) in paired Ussing chambers in response to addition of different concentrations of glycylsarcosine in control piglet jejunum (mean \pm SEM).

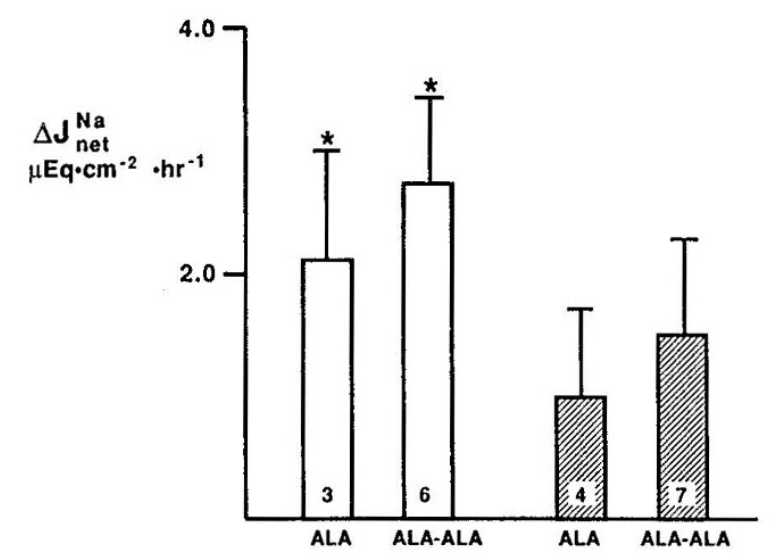

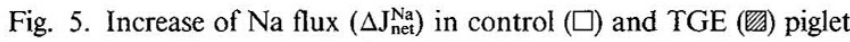
jejunum after addition of L-alanine $(A L A)(20 \mathrm{mM})$ or Ala-Ala $(10 \mathrm{mM})$ (mean \pm SEM). An asterisk indicates that the substrate significantly enhanced net $\mathrm{Na}$ absorption $(p<0.05)$.

increased sodium transport by a single carrier due to enhanced glucose metabolism. The response to $\mathrm{L}$-alanine with $3-\mathrm{O}-\mathrm{MG}$, a nonmetabolizable hexose transported by the same carrier pathway as other hexoses but with a reduced apparent receptor affinity compared with D-glucose (15), showed that the response to D-glucose with L-alanine cannot be attributed to a nonspecific effect of D-glucose on tissue metabolism. Increments in jejunal flux after adding 3-O-MG with L-alanine did not differ from the response to $\mathrm{D}$-glucose with $\mathrm{L}$-alanine. Thus, our data favor the interpretation that separate carrier systems for D-glucose and Lalanine are present in the jejunum in health and during viral enteritis.

In addition, we have identified a defect in L-alanine-facilitated $\mathrm{Na}$ absorption during acute viral diarrhea. Control piglet jejunum responded to either L-alanine or D-glucose with significant increments in net $\mathrm{Na}$ absorption, as previously reported in other mammalian (16) and nonmammalian (17) species. After TGE infection, there was a significant impairment of sodium transport response to either L-alanine or D-glucose (Table 2). Previous investigations from this laboratory have shown that TGE causes a significant reduction in transjejunal D-glucose-facilitated $\mathrm{Na}$ absorption (9) and impairment of brush border membrane $\mathrm{Na}$ gradient-driven D-glucose transport (18). Therefore, our finding of a defect in a similar but distinct epithelial transport system (19-22), that of neutral amino acid-sodium cotransport, might have been anticipated in this acute enteritis. Previous studies (13) and the current enzyme and morphologic data suggest that the epithelium is composed of relatively undifferentiated crypttype enterocytes during acute TGE diarrhea. We speculate that these crypt-like cells are defective in the $\mathrm{Na}$ absorptive response both to neutral amino acid and to D-glucose.

Certain dipeptides have been reported to be absorbed more efficiently than their constituent amino acids both in normal volunteers (25) and in patients with celiac disease $(24,25)$. Dipeptides do not compete with amino acids for mucosal uptake (23) and they have been found to increase $\mathrm{Na}$ absorption in man (3). Because transport of a poorly hydrolyzed dipeptide, glycylsarcosine, into hamster intestinal rings was reduced by metabolic inhibitors and by replacement of mucosal $\mathrm{Na}$ with potassium (14), dipeptides were thought to be cotransported with $\mathrm{Na} \mathrm{(23).}$ However, evidence is accumulating that "uphill" Na-driven transport of dipeptides may not occur in the brush border of small intestine (26-28). Probably the effect of Ala-Ala on sodium transport in our studies resembled that of L-alanine because the dipeptide was hydrolyzed rapidly at the brush border surface of both control and TGE tissue. The failure of $\mathrm{Na}$ transport to respond to glycylsarcosine in control jejunum further supports the emerging concept that $\mathrm{Na}$ gradient-dependent dipeptide transport may not occur. The observed concentration-dependent increase in transmucosal Isc in response to glycylsarcosine, indicating stimulation of electrogenic transport in the absence of a change in $\mathrm{Na}$ flux, might be attributable to a recently postulated dipeptide- $\mathrm{H}^{+}$cotransport mechanism in intestinal brush border $(28,29)$.

That the relatively poorly differentiated epithelium characterizing viral enteritis responds better to glucose combined with an amino acid than to either of these substrates alone could have implications for the oral treatment of viral diarrhea. The ORS now advocated by WHO is much more effective than earlier traditional treatments for children with acute enteritis $(1,2,30$ 32). Nevertheless, between 7 and $15 \%$ of children treated with ORS for dehydration resulting from viral diarrhea receive intravenous therapy, often because stool losses continue to exceed oral fluid intake $(1,31,32)$. Our data support the clinical evaluation of an appropriate amino acid in an oral rehydration solution to improve Na and water absorption. Several clinical trials have shown that modestly hypertonic oral treatment solutions containing amino acid may reduce stool output as well as oral fluid requirements in patients with acute diarrhea $(4,5,33)$. However, based on our limited experiments, the addition of dipeptides to an oral treatment solution would not be expected to confer an absorptive advantage over amino acids.

Acknowledgments. The authors are grateful to Krys Streich, Mahmood Khan, Helen Conway, Emil Katona, William Wilson, and Dr. Celina Guzman for expert technical assistance; to Shelley Goodman for secretarial assistance; and to the Medical Publications Department, The Hospital for Sick Children, for their help in the preparation of this paper.

\section{REFERENCES}

1. Sack DA, Eusof A, Merson MH, Black RE, Chowdhury AMAK, Ali MA, Islam S, Brown KH 1978 Oral hydration in rotavirus diarrhoea: a double blind comparison of sucrose with glucose electrolyte solution. Lancet 2:280283

2. Santosham M, Daum RS, Dillman L, Rodriguez JL, Luque S, Russell R, Kourany M, Ryder RW, Bartiett AV, Rosenberg A, Benenson AS, Sack RB 1982 Oral rehydration therapy of infantile diarrhea: a controlled study of well-nourished children hospitalized in the United States and Panama. N Engl J Med 306:1070-1076

3. Hellier MD, Thirumalai C, Holdsworth CD 1973 The effect of amino acids and dipeptides on sodium and water absorption in man. Gut 14:41-45

4. Patra FC, Mahalanabis D, Jalan KN, Sen A, Banerjee P 1984 In search of a super solution: controlled trial of glycine-glucose oral rehydration solution in infantile diarrhoea. Acta Pediatr Scand 73:18-21

5. Nalin DR, Cash RA, Rahman M, Yunus M 1970 Effect of glycine and glucose on sodium and water absorption in patients with cholera. Gut 11:768-772 


\section{ALANINE STIMULATES NA TRANSPORT IN DIARRHEA}

6. Butler DG, Gall DG, Kelly MH, Hamilton JR 1974 Transmissible gastroenteritis: mechanisms responsible for diarrhea in an acute viral enteritis in piglets. J Clin Invest 53:1335-1342

7. Dahlqvist A 1964 Method for assay of intestinal disaccharidases. Anal Biochem $7: 18-25$

8. Kelly M, Butler DG, Hamilton JR 1972 Transmissible gastroenteritis in piglets: a model of infantile viral diarrhea. J Pediatr 80:925-931

9. Kerzner B, Kelly MH, Gall DG, Butler DG, Hamilton JR 1977 Transmissible gastroenteritis: sodium transport and the intestinal epithelium during the course of viral enteritis. Gastroenterology 72:457-461

10. Field M, Fromm D, McColl I 1971 Ion transport in rabbit ileal mucosa. I. Na and $\mathrm{Cl}$ fluxes and short-circuit current. Am J Physiol 220:1388-1396

11. Schultz SG, Zalusky R 1964 Ion transport in isolated rabbit ileum. I. Shortcircuit current and Na fluxes. J Gen Physiol 47:567-584

12. Field M, Schultz SG, Curran PF 1967 Alanine transport across isolated rabbit ileum. Biochim Biophys Acta 135:236-243

13. Hamilton JR, Gall DG, Butler DG, Middleton PJ 1976 Viral gastroenteritis: recent progress, remaining problems. Ciba Found Symp 42:209-222

14. Addison JM, Burston D, Matthews DA 1972 Evidence for active transport of the dipeptide glycylsarcosine by hamster jejunum in vitro. Clin Sci 43:907911

15. Schultz SG, Zalusky R 1964 Ion transport in isolated rabbit ileum. II. The interaction between active sodium and active sugar transport. J Gen Physiol 47:1043-1059

16. Munck BG 1981 Intestinal absorption of amino acids. In: Johnson LR (ed) Physiology of the Gastrointestinal Tract. Raven Press, New York, pp 1097 1122

17. Gunter-Smith PJ, Grasset E, Schultz SG 1982 Sodium-coupled amino acid and sugar transport by Necturus small intestine. An equivalent electrical circuit analysis of a rheogenic co-transport system. J Membr Biol 66:25-39

18. Keljo DJ, MacLeod RJ, Perdue MH, Butler DG, Hamilton JR 1985 D-glucose transport in piglet jejunal brush-border membranes: insights from a disease model. Am J Physiol 249:G751-G760

19. Frizzell RA, Schultz SG 1971 Distinction between galactose and phenylalanine effects on alanine transport in rabbit ileum. Biochim Biophys Acta 233:485488

20. Semenza G 1971 On the mechanism of mutual inhibition among sodiumdependent transport systems in the small intestine. A hypothesis. Biochim Biophys Acta 241:637-649

21. Murer H, Sigrist-Nelson K, Hopfer U 1975 On the mechanism of sugar and amino acid interaction in intestinal transport. J Biol Chem 250:7392-7396

22. Munck BG 1980 Transport of sugars and amino acids across guinea pig small intestine. Biochim Biophys Acta 597:411-417

23. Matthews DM 1975 Intestinal absorption of peptides. Physiol Rev 55:537-611

24. Silk DBA, Kumar PJ, Perrett D, Clark ML, Dawson AM 1974 Amino acid and peptide absorption in patients with coeliac disease and dermatitis herpetiformis. Gut 15:1-8

25. Adibi SA, Fogel MR, Agarwal RM 1974 Comparison of free amino acid and dipeptide absorption in the jejunum of sprue patients. Gastroenterology $67: 586-591$

26. Cheeseman CI 1980 The transport of dipeptides by the small intestine. Can J Physiol Pharmacol 58:1326-1333

27. Ganapathy V, Leibach FH 1982 Minireview: peptide transport in intestinal and renal brush border membrane vesicles. Life Sci 30:2137-2146

28. Ganapathy V, Leibach FH 1983 Role of $\mathrm{pH}$ gradient and membrane potential in dipeptide transport in intestinal and renal brush-border membrane vesicles from the rabbit. Studies with L-carnosine and glycyl-L-proline. J Biol Chem 258:14189-14192

29. Ganapathy V, Burckhardt G, Leibach FH 1984 Characteristics of glycylsarcosine transport in rabbit intestinal brush-border membrane vesicles. J Biol Chem 259:8954-8959

30. Hirschhorn N 1980 The treatment of acute diarrhea in children: an historical and physiological perspective. Am J Dis Child 33:637-663

31. Taylor PR, Merson MH, Black RE, Rahman ASMM, Yunus M, Alim ARMA, Yolken RH 1980 Oral rehydration therapy for treatment of rotavirus diarrhoea in a rural treatment center in Bangladesh. Arch Dis Child 55:376-379

32. Black RE, Merson MH, Taylor PR, Yolken RH, Yunus M, Alim ARMA, Sack DA 1981 Glucose vs sucrose in oral rehydration solutions for infants and young children with rotavirus-associated diarrhea. Pediatrics 67:79-83

33. Nalin DR, Cash RA 1970 Oral or nasogastric therapy for diarrhoea of unknown aetiology resembling cholera. Trans $R$ Soc Trop Med Hyg 64:769-771 